\title{
Development of Folding Seats (Comfort, Easy, and Safety) During Use
}

\author{
Fadhila Lady Sifredy ${ }^{1}$, Nur Isnaeni ${ }^{2}$ \\ ${ }^{1.2}$ Department of Health, Universitas Muhammadiyah Purwokerto, Indonesia
}

\begin{tabular}{l} 
ARTICLE INFO \\
\hline Article history: \\
DOI: \\
$\underline{10.30595 / p s h m s . v 2 i .252}$
\end{tabular}

Submitted:

December 6, 2021

Accepted:

January 21, 2022

Published:

January 26, 2022

\begin{abstract}
The elderly in carrying out activities both indoors and outdoors will experience difficulties due to their declining physical condition. Therefore, they will need extra time and effort and tend to tire easily and feel sore when doing various activities (such as sitting, walking, or standing for too long). It is necessary to produce a product that can help and make the elderly more comfortable in carrying out activities. Designing and developing a folding seat for the feasibility and comfort and safety of the seat mat. Tried the use of a folding seat mat. This research is a Research and Development (R\&D) research. The sampling technique is purposive sampling with a total of 5 elderly people. The research instrument used a questionnaire. Data analysis using frequency distribution test. Research results Characteristics of respondents have an average age of 66.4 years with the youngest age 61 years and the oldest age is 70 years. The comfort level of using the Elderly Sitting Mat has an average comfort level of 33.8. The model or display of the seat used has a length of $150 \mathrm{~cm}$ and a width of $50 \mathrm{~cm}$. This seat mat is equipped with safety on the right and left with a length of $35 \mathrm{~cm}$, and there are recesses to adjust the angle of the backrest so that it can be adjusted as needed. This folding seat mat can be folded for easy storage. The level of comfort for the elderly when using the Folding Seat is in the very good category The comfort level of using the Elderly Sitting Mat has an average comfort level of 33.8. The model or display of the seat used has a length of $150 \mathrm{~cm}$ and a width of $50 \mathrm{~cm}$. This seat mat is equipped with safety on the right and left with a length of $35 \mathrm{~cm}$, and there are recesses to adjust the angle of the backrest so that it can be adjusted as needed. This folding seat mat can be folded for easy storage. The level of comfort for the elderly when using the Folding Seat is in the very good category The comfort level of using the Elderly Sitting Mat has an average comfort level of 33.8. The model or display of the seat used has a length of $150 \mathrm{~cm}$ and a width of 50 $\mathrm{cm}$. This seat mat is equipped with safety on the right and left with a length of $35 \mathrm{~cm}$, and there are recesses to adjust the angle of the backrest so that it can be adjusted as needed. This folding seat mat can be folded for easy storage. The level of comfort for the elderly when using the Folding Seat is in the very good category.
\end{abstract}

Keywords:

Tlevel Comfort; Elderly; Folding Seating

This work is licensed under aCreative Commons Attribution 4.0 International License.

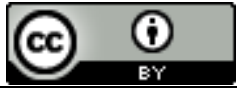

\section{Corresponding Author:}

Nur Isnaini,

Department of Health, Universitas Muhammadiyah Purwokerto,

Soepardjo Rustam Street KM. 7, Banyumas, Indonesia

E-mail: nurisnaini@ump.ac.id

\section{INTRODUCTION}

Folding Seator Folding Sitting Mat is a seat that can be folded and makes it easier for users to store and use. Folding Seat can be used by anyone, especially the elderly. Elderly is a process of growth and development that occurs in humans, the elderly itself is a phase of declining intellectual and physical abilities, which begins with some life changes. As is known, when humans reach adulthood, they have the 
ability to reproduce and give birth to children. Living conditions change, a person will lose this task and function, and enter the next stage, namely old age. [1]

Indonesia is a country that is entering the era of aging structured population because it has a population of around $7.18 \%$ aged 60 years and over, which will have an impact on increasing increasingly complex elderly problems, from health problems to degenerative diseases to the mental status of the elderly. Makhfud \& Effendi, 2009). This is based on increasing age, the possibility of an anatomic and physiological decline in the organs getting bigger. [1]

Physiological changes vary in each elderly, some elderly are unable to carry out activities or their activities are limited due to physical, emotional, or social problems that make the elderly feel sick. With the emergence of pain felt by the elderly, eating will result in the elderly being unproductive, especially in terms of activities and limitations in caring for themselves independently. [2]

The problem of low back pain arising from prolonged sitting is a phenomenon that often occurs today. Sitting for a long time in the wrong position can cause the lower back muscles to become tense and can damage the surrounding soft tissues. If this situation continues, it will cause pressure on the spinal cord which results in a herniated nucleus pulposus. [3]

Complaints on the back or musculoskeletal complaints are complaints of skeletal muscles that are felt with different pain intensities, from mild pain to very painful pain. Muscles that receive static loads that are repeated and for a long time can cause complaints in the form of damage to joints, ligaments and tendons. [4]

In general, skeletal muscle complaints begin to be felt at working age, which is 25-65 years. Where the main complaint is felt at the age of 35 years and increases with age. Pain is an important sensation for the body. The provocation of pain sensory nerves produces an uncomfortable reaction of distress, or suffering. Back pain can also be caused by the shift of one of the bearings between the spine or pressure on the pelvic nerves, one of which is caused by a sitting position for too long. [5]

Based on research by Mia Arianti Nuriman et al (2018) which said that in carrying out activities the elderly would experience difficulties due to declining physical conditions. Therefore they need time to rest because they tend to get tired easily. From the problems that exist, researchers produce a product that can help and make the elderly more comfortable in carrying out activities. This product is a seating facility that can be moved and is suitable for outdoor and indoor. [6]

Based on research by Grondin et al (2013) which said several risk factors for low back pain, including prolonged sitting and flexed spinal curvature. In this study creating a lumbar support pillow with a cut for the posterior pelvic tissue increases an objective measure of comfort in healthy individuals and patients with low back pain. [7]

Based on research conducted by Raharjo (2018) which says that about $60 \%$ to $80 \%$ of the world's population has experienced at least one episode of back pain during their lifetime. This study seeks to create a prototype of a tool that can be used to prevent back pain. This assistive device is expected to be able to familiarize its users to sit in the correct position and prevent back pain from appearing. [8]

Based on research conducted by Hidayat (2017) which says that some of the elderly carry out daily activities such as eating, nebyukam, and others are carried out in bed. Therefore, the researchers improved the old design and the new design in accordance with the expectations of users to improve the functions and needs of the sensor as follows, bed frames, headrests, equipment for building and supporting needs. Improvements were made to accommodate all activities by prioritizing the elderly in terms of comfort during use. [9]

In Pasir Wetan Village, there are elderly people who have a habit of sitting too long on the floor without using a soft seat and not using a comfortable backrest for their back, this habit will have an impact on the spine. The elderly can sit for hours because they do not have activities and have a lot of free time, so the elderly in Pasir Wetan Village prefer to spend their time sitting and relaxing.

This condition often becomes chronic, persistent, or sometimes recurring and should not be underestimated. Getting old (aging) is a process of losing the ability of the network to repair itself slowly and maintain its normal structure and function. [10]

Based on the above background, to improve sitting comfort, especially in the elderly. So this research will create a "Folding Seat" which prioritizes comfort and security for users.

\section{RESEARCH METHOD}

This study uses the Research and Development (R\&D) method, Research and Development research is a research method used to produce certain products, and test the effectiveness of these products. The research development procedure basically consists of two main objectives, namely developing the product, and testing the effectiveness of the product in achieving the goal. The first objective is called the development function while the second objective is called as validation. Thus, the concept of development 
research is more accurately defined as a development effort which is also accompanied by validation efforts. Research and Development (R\&D).

According to Sugiyono (2014), there are several research steps in the Research and Development research method as follows:

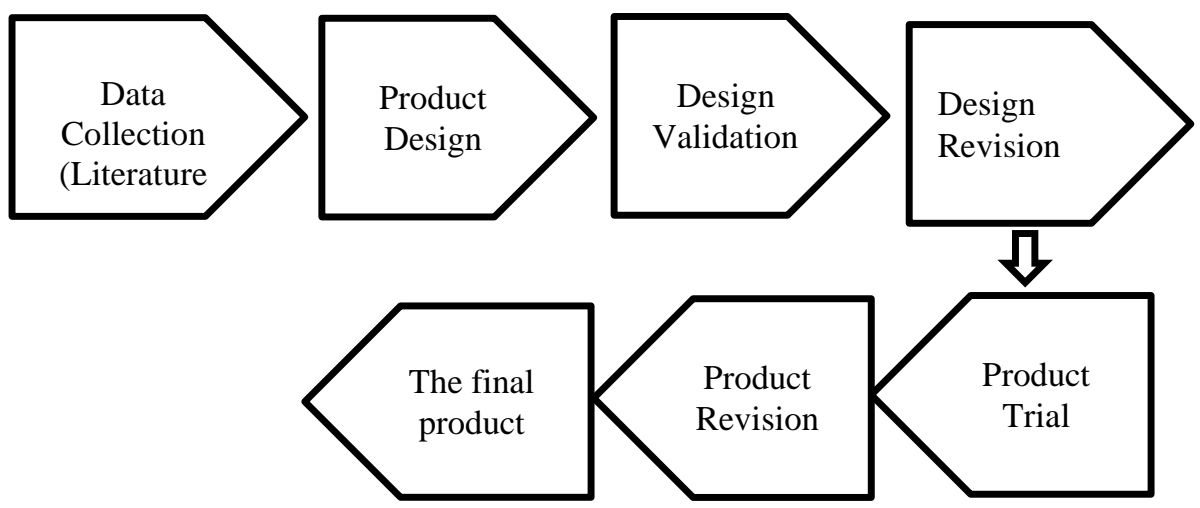

3. RESULTS AND DISCUSSION

1. Description of respondents' characteristics by age.

Table 1 Frequency Distribution of Respondents' Characteristics by Age

\begin{tabular}{cccc}
\hline Variable & mean & median & Min-Max \\
\hline Age & 66.4 & 67 & $61-70$ \\
\hline
\end{tabular}

Based on table 4.1, it is known that the average age of respondents is 66.4 years with the youngest age 61 years and the oldest age being 70 years.

2. Product of Sitting Mat Technology for the Elderly

Technological works makesitting mats that can be used by the elderly in accordance with the needs to increase the comfort of the elderly when sitting. This technological work starts from identification, manufacturing process, feasibility test, to distributing questionnaires to respondents to find out respondents' opinions regarding the comfort response of using a sitting mat. The following is the seat for the elderly:

Figure 1 Seating Display

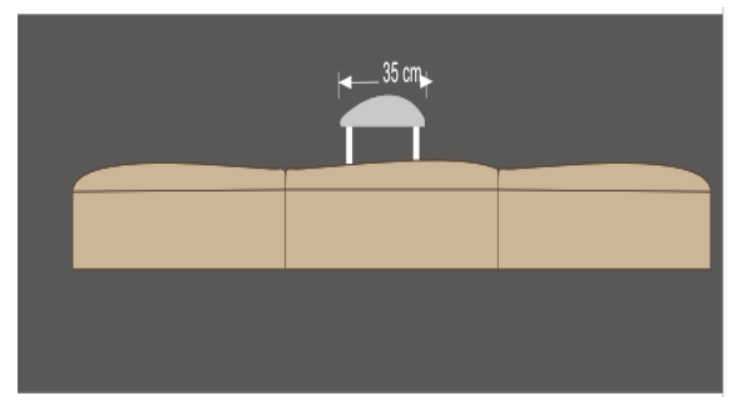

Figure 4.1 describes the model or appearance of the seat that will be used where this seat has a length of $150 \mathrm{~cm}$ and a width of $50 \mathrm{~cm}$. This seat mat is equipped with safety on the right and left with a length of $35 \mathrm{~cm}$. 
Figure 2 Display of the Use of Sitting Mats

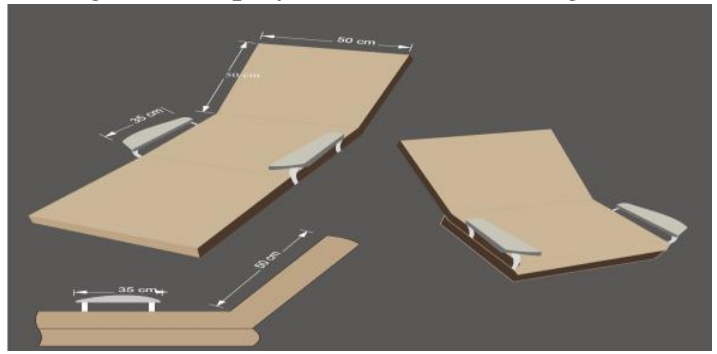

Figure 4.2 explains that the elderly seat mat can be used according to the elderly seat, both long and high models.

Technological works makesitting mats that can be used by the elderly in accordance with the needs to increase the comfort of the elderly when sitting. This technological work starts from identification, manufacturing process, feasibility test, to distributing questionnaires to respondents to find out respondents' opinions regarding the comfort response of using a sitting mat. The model or display of the seat used has a length of $150 \mathrm{~cm}$ and a width of $50 \mathrm{~cm}$. This seat mat is equipped with safety on the right and left with a length of $35 \mathrm{~cm}$. This seat mat can be used according to the elderly seat, both long and tall models.

\section{Comfort Level of Using Sitting Mat}

The results of the research on the level of comfort in the use of seating mats that have been carried out on 5 respondents can be seen in the diagram below:

Table 2 General Comfort Level

\begin{tabular}{cccc}
\hline Variable & mean & median & Min-Max \\
\hline $\begin{array}{c}\text { Comfort } \\
\text { Level }\end{array}$ & 33.8 & 35 & $30-36$ \\
\hline
\end{tabular}

Based on table 4.2, it is known that from 5 elderly people the average comfort level value is 33.8 with the lowest comfort level value being 30 and the highest being 36 . The results of the study also found that 2 respondents gave a comfort rating of $36(40 \%)$.

The results of the study also found that the level of comfort in using a sitting mat in the study could be seen from the 10 indicators as follows:

\begin{tabular}{cccc} 
Table 3 Satisfaction Indicators Use of Sitting Mat \\
\hline Indicator & mean & Min & Max \\
\hline Question No. 1 & 3.8 & 3 & 4 \\
Question No. 2 & 3.8 & 3 & 4 \\
Question No. 3 & 3.4 & 3 & 4 \\
Question No 4 & 3.4 & 2 & 4 \\
Question No 5 & 3.4 & 3 & 4 \\
Question No. 6 & 3.2 & 2 & 4 \\
Question No 7 & 3.2 & 1 & 4 \\
Question No 8 & 3 & 2 & 4 \\
Question No 9 & 3.6 & 3 & 4 \\
Question No 10 & 3 & 2 & 4 \\
\hline
\end{tabular}

Table 4.3 shows that in particular, out of 5 respondents gave the highest score on indicators no. 1 and 2 , which are related to the comfort of using a sitting mat, while the lowest value was given to indicators no. 8 and 9 , which is related to the use of iron sitting mats and the safety of sitting mats.

The results of the study on the level of comfort in using a sitting mat show that the average comfort level is 33.8 with the lowest comfort level value being 30 and the highest being 36 . The results also showed that as many as 2 respondents gave a comfort rating of $36(40 \%)$.

The results of the study also found that the level of comfort in the use of sitting mats in the study can be seen from 10 indicators, the highest values in indicators no. 1 and 2 are related to the comfort of using sitting mats while the lowest values are given to indicators no. 8 and 9, which are related to the use of iron and seat safety. According to the researcher's assumption, the comfort felt by the elderly because the seat 
used can be adjusted to the needs of the elderly. The use of the basic material of foam makes the elderly feel comfortable because the foam material is soft and also soft, but the use of an iron frame makes the elderly feel less comfortable and less secure because they are afraid that if the iron frame is damaged it can be dangerous.

Research conducted by Hidayat (2017) which says that some of the elderly carry out daily activities such as eating, nebyukam, and others are carried out in bed. Therefore, the researchers improved the old design and the new design in accordance with the expectations of users to improve the functions and needs of the sensor as follows, bed frames, headrests, equipment for building and supporting needs. Improvements were made to accommodate all activities by prioritizing the elderly in terms of comfort during use

Based on the results of the study, it is known that the elderly have a high level of comfort related to the seat provided. This is because the elderly are an age group that is susceptible to falling risk due to balance disorders when standing from sitting, the seat mat used in this study can adjust the needs of the elderly so that it can help the elderly to make it easier to get up from sitting and reduce balance disorders.

\section{CONCLUSION}

Based on the results of research and discussion, it can be concluded that the average respondent's characteristics are 66.4 years old with the youngest age 61 years and the oldest age being 70 years. The model or display of the seat used has a length of $150 \mathrm{~cm}$ and a width of $50 \mathrm{~cm}$. This seat mat is equipped with safety on the right and left with a length of $35 \mathrm{~cm}$. The comfort level of using Sitting Mats for the Elderly has an average comfort level of 33.8, the highest value is in indicators no. 1 and 2, which are related to the comfort of using seating mats, while the lowest values are given to indicators no. 8 and 9 , which are related to the use of iron sitting mats and the safety of the mats. sit.

\section{Acknowledgments}

Thank you to Allah SWT, both parents and all comrades in arms who have helped from beginning to end.

\section{REFERENCES}

[1] Darmojo, "Gerontic Nursing," Jakarta; EGC, 2010.

[2] Maryam, R. Ekasari, M. Rosidawati. Jubaedi, A. \& Batubara I., "Knowing the Elderly and Its Treatment," Jakarta: Salemba Medika, 2010.

[3] Idyan, Z., "The Relationship of Long Sitting During Lectures With Complaints of Low Back Pain," 2007. Accessed from: http://www.innappni.or.id

[4] Tarwaka, "Industrial Ergonomics," Surakarta: Harapan Press, 2014.

[5] Simon, D., "A systematic review of low back pain cost of illness studies in the United States and internationally," The Spine Journal, 8(1): 8-20, 2008.

[6] Nuriman, M.A., "Perancangan fasilitas duduk moveable untuk lansia," Intra Journal, Vol.6, No.1, 2018.

[7] Grondin, A, Kieso, "The effect of lumbar support pillow on lumbar posture and comfort during a prolonged seated task," Biomed Central. 2(3):9, 2013.

[8] Raharjo, T., "Ergonomics Bycycle Cycling Positioner Designer," Muhammadiyah Surakarta University, 2018. 